INGENIERÍA DE MATERIALES

\title{
Synthesis and chemical and structural characterization of hydroxyapatite obtained from eggshell and tricalcium phosphate
}

MATERIALS ENGINEERING

\section{Síntesis y caracterización química y estructural de hidroxiapatita sintetizada a partir de cáscara de huevo y fosfato tricálcico}

\author{
Alejandro Arboleda*, Manuel Franco*, Julio Caicedo**,*, Liliana \\ Tirado***, Clara Goyes*\$ \\ *Universidad Autónoma de Occidente. Cali, Colombia. \\ **Facultad de Ingeniería Universidad del Valle, Cali-Colombia. \\ ***Universidad del Quindio. Armenia, Colombia. \\ alejandro.arboleda@outlook.com,mfranco9009@hotmail.com,jcaicedoangulo1@gmail.com, \\ litirado@uniquindio.edu.co,§cegoyes@uao.edu.co
}

(Recibido: Abril 24 de 2015 - Aceptado: Agosto 20 de 2015)

\begin{abstract}
Resumen
La cáscara de huevo es un residuo común que generalmente se desecha sin darle uso alguno. En este trabajo se presenta una metodología experimental que usa la cáscara de huevo para obtener un biocerámico muy conocido en el campo de la ingeniería de los materiales y la biomédica, llamado hidroxiapatita (HA). La HA es un fosfato de calcio, su fórmula química es Ca10(PO4)6(OH)2 y tiene características físico-químicas muy similares a la del hueso humano, lo cual la convierte en uno de los biomateriales más usados como injertos o sustitutos para reparación ósea. Este material generalmente tiene un alto costo y se presenta en forma micro y nanoestructurada, ta última, la opción en nanotecnología más promisoria para la ingeniería de tejidos. La caracterización en este estudio incluye difracción de rayos X, en donde los difragtogramas obtenidos permiten la identificación de hidroxiapatita, con fase cúbica fcc (111), (102), (211), y la fase hexagonal hcp (h-211) y (h-322). Por otro lado se presentan resultados de espectroscopia infrarroja con transformada de Fourier, en donde se determinaron los modos activos de vibración correspondientes a la hidroxiapatita. Finalmente, mediante microscopia electrónica de barrido se observó la topografía del polvo cerámico así como también la distribución morfológica obtenida.
\end{abstract}

Palabras Clave: Biocerámicas, cáscara de huevo, hidroxiapatita, regeneración ósea.

\begin{abstract}
The eggshell is a common residue that is usually discarded without giving any use to it. In this paper the results obtained from a proposed procedure to get hydroxyapatite (HA) from eggshell are shown. The HA is a calcium phosphate which has been widely used as implant material due to the close similarity of its composition with the inorganic phase of natural bone. HA generally has a high cost and it is presented as micro and nanostructured bioceramics; the last one is a promising option for tissue engineering nanotechnology. In this study, results of X-ray diffraction (XRD) showed the hydroxyapatite production exhibiting the characteristic peaks of this material for the cubic phase fcc (111), (102), (211), and for the hexagonal phase hcp (h-211) and (h-322). From the results of Fourier transform infrared spectroscopy (FTIR), it was possible to determine the active modes of vibration corresponding to hydroxyapatite (Ca10 $(\mathrm{PO} 4) 6(\mathrm{OH}) 2)$. From the results of scanning electron microscopy, it was determined the topography of the ceramic powder as well as its morphological distribution.
\end{abstract}

Keywords: Bioceramics, bone regeneration, eggshell, hydroxyapatite. 


\section{Introduction}

The eggshell is considered as residue and it is made up of calcium carbonate ( $94 \%$ ), calcium phosphate $(1 \%)$, magnesium carbonate $(1 \%)$, and organic matter (4\%) (Stadelman, 2000). The eggshell is basically unused after the production of the egg and its derivates. In the literature, there are few reports on the use of this residue and the companies that generate it, considering it as an industrial residue that might contribute to pollution, since it favors the microbial proliferation in the environment (Rivera et al., 1999). As an important source of calcium carbonate, the eggshell has been used as raw material in different fields of materials engineering, particularly as biosensor and in medicine (Balaz, 2014). In the biomedical field, there are some reports showing that the eggshell has been used in the manufacture of bioceramics to repair bone injuries (Rivera et al., 1999; Lee \& Oh, 2003). In Colombia, this residue is discarded and it is not common to find scientific alternatives that promote its reuse; this is why this study is aimed at exploring an alternative of use for the manufacturing of a type of bioceramics, with the purpose of contributing to the biomedical field, in case its production is optimized. In order to have an idea of the yearly production of eggshell in Colombia, it is estimated in 11'529.250 units in 2014, being Valle (Departments of Cauca, Nariño, and Valle del Cauca) the second most productive region at national level, with an estimate of 2'972'388 units in 2014 (FENAVI, 2014). At national level, 691,756 tons were produced (FENAVI, 2014).

The material that will be produced, known as hydroxyapatite (HA), has a structure composed of calcium, phosphorus, and hydroxyl ions $\left(\mathrm{Ca}_{10}\left(\mathrm{PO}_{4}\right)_{6}(\mathrm{OH})_{2}\right)$. Its biological importance is due to its capacity of allowing a perfect osseointegration, the absence of local and systemic toxicity, and the null genotoxic activity (Ginebra et al., 2006; Franco et al., 2014). HA associates with the surrounding bone in a tight and stable way, both chemically and physically, allowing the repairing processes develop as if they were two bone tissues in close contact (Ginebra et al., 2006).
Recent publications have demonstrated that HA at nanostructured scale increases significantly the biocompatibility and bioactivity of the man-made biodevices (Sadat-Shojai et al., 2013). Therefore, this study includes the comparison of the product obtained with commercial nano-hydroxyapatite, with the purpose of finding similar characteristics that lead to its optimization. One of the reported sources to synthesize HA is the eggshell (Rivera et al., 1999; Lee \& Oh, 2003), which comprises processes that take place in a high temperature environment and using phosphate solutions (Rivera et al., 1999; Balázsi et al., 2007; Lee \& Oh, 2003). In these reports, the obtaining of HA has been done from precursors, either tricalcium phosphate, Ca3 (PO4)2 (Rivera et al., 1999) or phosphoric acid, H3PO4 (Balázsi et al., 2007; Lee $\& \mathrm{Oh}, 2003)$. In the case of tricalcium phosphate (TCP), it has been reported for producing HA in an already established relation of $\mathrm{Ca} / \mathrm{P}$ (Rivera et al., 1999) but it is recommended to optimize the composition of the solutions used, the time, and the temperature of annealing (Rivera et al., 1999). This study reports an experimental methodology for the synthesis of hydroxyapatite from eggshell taking into consideration a variation in the content of $\mathrm{CaO}$ and tricalcium phosphate $\mathrm{Ca}_{3}\left(\mathrm{PO}_{4}\right)_{2}$, in order to find the parameters that generate a high content of crystalline hydroxyapatite.

\section{Methodology}

The process for manufacturing hydroxyapatite (HA) starts with an eggshell mechanic milling stage to get a white powder. A first stage of heating eggshells at $450^{\circ} \mathrm{C}$ for two hours is carried out in order for the organic residue to be destroyed and $\mathrm{CaCO}_{3}$ to be obtained (Rivera et al., 1999). In this study, the particle grain size was taken into consideration; therefore, a sieving was done using different filter sizes starting from an average grain size of $54 \mu \mathrm{m}$ up to $74 \mu \mathrm{m}$. Afterwards, a heat treatment of calcium carbonate powder $\mathrm{CaCO}_{3}$ was done during two hours at $900^{\circ} \mathrm{C}$, using a Type 30400 Thermolyne furnace in order to ensure its transformation into $\mathrm{CaO}$ through the release of carbon dioxide $\left(\mathrm{CO}_{2}\right)$, as presented in Ec. 1 .

$$
\mathrm{CaCO}_{3} \rightarrow \mathrm{CO}_{2}+\mathrm{CaO}
$$


Then, HA is obtained using the precursors tricalcium phosphate $\left(\mathrm{Ca}_{3}\left(\mathrm{PO}_{4}\right)_{2}\right.$, calcium oxide $\mathrm{CaO}$ and water $\left(\mathrm{H}_{2} \mathrm{O}\right)$, as described in Ec. 2.

$$
3 \mathrm{Ca}_{3}\left(\mathrm{PO}_{4}\right)_{2}+\mathrm{CaO}+\mathrm{H}_{2} \mathrm{O} \rightarrow \mathrm{Ca}_{10}\left(\mathrm{PO}_{4}\right)_{6}(\mathrm{OH})_{2}
$$

In this work, an experimental study for manufacturing HA was carried out; in it, particle size, temperature ramp, and concentration of precursors are varied, as shown in Table 1. Figure 1 shows a flow chart that summarizes the experimental methodology used in this study.
In order to determine the crystalline structure of the hydroxyapatite, a Bruker D8 Advance diffractometer in the coupled mode $\theta-2 \theta$ was used. The analysis of vibrational mode of the material were determined through spectroscopy in the infrared with Fourier transform (FTIR) through a Shimadzu 8000 spectrometer $\left(550-1000 \mathrm{~cm}^{-1}\right)$ in transmittance mode, which uses a ceramic source Nerst type. The spectra of FTIR and diffractograms of X-ray, for all the cases are compared with commercial nano-hydroxyapatite samples, known as FLUIDINOVA - nanoXIM-HAp202. The morphology of the samples was observed

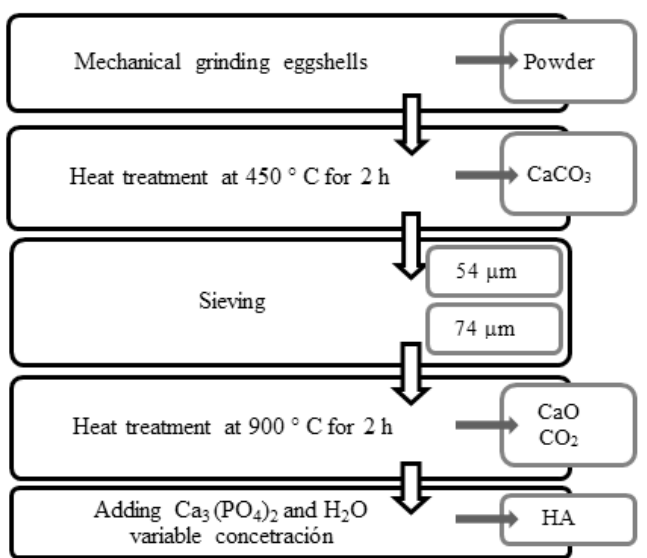

Figure 1. Summary of the process used to obtain hydroxyapatite from eggshell.

Tabla 1. Experimental design for obtaining the samples.

\begin{tabular}{|c|c|c|c|c|c|c|}
\hline Sample No. & $\begin{array}{c}\text { Sieve } \\
\text { size }\end{array}$ & $\begin{array}{c}\text { Ramp of } \\
\text { temperature }\end{array}$ & {$[\mathrm{CaO}]$} & {$\left[\mathrm{Ca}_{3}\left(\mathrm{PO}_{4}\right)_{2}\right]$} & $\begin{array}{c}\text { Final temperatures of } \\
\text { thermal treatment }\end{array}$ & Timing \\
\hline M1 & $54 \mu \mathrm{m}$ & $10^{\circ} \mathrm{C} / \mathrm{min}$ & $95 \%$ & $5 \%$ & $1060^{\circ} \mathrm{C}$ & $7 \mathrm{~h}$ \\
\hline M2 & $54 \mu \mathrm{m}$ & $10^{\circ} \mathrm{C} / \mathrm{min}$ & $85 \%$ & $15 \%$ & $1060^{\circ} \mathrm{C}$ & $7 \mathrm{~h}$ \\
\hline M3 & $54 \mu \mathrm{m}$ & $10^{\circ} \mathrm{C} / \mathrm{min}$ & $75 \%$ & $25 \%$ & $1060^{\circ} \mathrm{C}$ & $7 \mathrm{~h}$ \\
\hline M4 & $54 \mu \mathrm{m}$ & $10^{\circ} \mathrm{C} / \mathrm{min}$ & $50 \%$ & $50 \%$ & $1060^{\circ} \mathrm{C}$ & $7 \mathrm{~h}$ \\
\hline M5 & $74 \mu \mathrm{m}$ & $15^{\circ} \mathrm{C} / \mathrm{min}$ & $95 \%$ & $5 \%$ & $1060^{\circ} \mathrm{C}$ & $7 \mathrm{~h}$ \\
\hline M6 & $74 \mu \mathrm{m}$ & $15^{\circ} \mathrm{C} / \mathrm{min}$ & $85 \%$ & $15 \%$ & $1060^{\circ} \mathrm{C}$ & $7 \mathrm{~h}$ \\
\hline M7 & $74 \mu \mathrm{m}$ & $15^{\circ} \mathrm{C} / \mathrm{min}$ & $75 \%$ & $25 \%$ & $1060^{\circ} \mathrm{C}$ & $7 \mathrm{~h}$ \\
\hline M8 & $74 \mu \mathrm{m}$ & $15^{\circ} \mathrm{C} / \mathrm{min}$ & $50 \%$ & $50 \%$ & $1060^{\circ} \mathrm{C}$ & $7 \mathrm{~h}$ \\
\hline M9 & $54 \mu \mathrm{m}$ & $10^{\circ} \mathrm{C} / \mathrm{min}$ & $100 \%$ & - & $900{ }^{\circ} \mathrm{C}$ & $5 \mathrm{~h}$ \\
\hline M10 & $74 \mu \mathrm{m}$ & $15^{\circ} \mathrm{C} / \mathrm{min}$ & $100 \%$ & - & $900{ }^{\circ} \mathrm{C}$ & $5 \mathrm{~h}$ \\
\hline M11 & \multicolumn{6}{|c|}{ Commercial HA } \\
\hline
\end{tabular}


through a Scanning Electron Microscope (SEM) FEI QUANTA 200, equipped with an optical light that has a magnifying range of 525-24,000 $X$ and a high sensibility detector (multi-mode) for dispersion electrons.

\section{Results and discussion}

\subsection{Analysis of infrared spectroscopy}

In the spectra obtained through FTIR, numerous transmission bands in the region of near and middle infrared can be observed; however, the most relevant are associated with the vibrations corresponding to P-O, Ca-O y O-H. Figure 2a shows the FTIR spectra of the M1 and M4 samples, corresponding to the hydroxyapatite obtained with different percentages of $\mathrm{CaO}$, with particle size $54 \mu \mathrm{m}$, heating rate $10^{\circ} \mathrm{C} / \mathrm{min}$, at a sintering temperature $1060{ }^{\circ} \mathrm{C}$ and 7 hours; for comparison purposes, the spectrum of the commercial sample is included. When we analyze Figure $2 \mathrm{a}$, an active vibration mode is found around $571 \mathrm{~cm}^{-1}$ and 601 $\mathrm{cm}^{-1}$ for bonds $\mathrm{O}-\mathrm{P}-\mathrm{O}$ of HA flexion type (v4), which are moderately visible for spectra of the samples of HA obtained from eggshell. On the other hand, it is visible when compared to the commercial sample, a transmittance band around $1415 \mathrm{~cm}^{-1}$ regarding to $\mathrm{C}-\mathrm{O}$ of $\mathrm{CO}_{3}{ }^{2-}$ stretching type (Siriphannon et al., 2002). The spectrum of the commercial sample presents a band in $3570 \mathrm{~cm}^{-1}$ corresponding to the groups $\mathrm{O}-\mathrm{H}$ of symmetric stretching according to the reports by Siriphannon and Delgado (Siriphannon et al., 2002; Delgado et al., 1996). This band is also moderately evident for the samples manufactured for this study. The vibration centered in the band of $3570 \mathrm{~cm}^{-1}$ corresponds to $\mathrm{O}-\mathrm{H}$ bonds of stretching type (Pramanik et al., 2005). Figure $2 \mathrm{~b}$ shows the band of absorbance around $1080 \mathrm{~cm}^{-1}$ of the FTIR spectrum in the sample of commercial nano-hydroxyapatite. These results allow determining the contribution corresponding to the symmetrical stretching type $\mathrm{P}-\mathrm{O}$ bonds of $\mathrm{HA}(v 3)$ (Siriphannon et al., 2002) and to the secondary phase vibrations such as O-Ca-O, Ca-O, P-O and $\mathrm{Ca}-\mathrm{O}-\mathrm{P}$, which characterize hydrated calcium phosphates and synthesized hydroxyapatite with the stoichiometric relation of $\mathrm{Ca}_{10}\left(\mathrm{PO}_{4}\right)_{6}(\mathrm{OH})_{2}$.

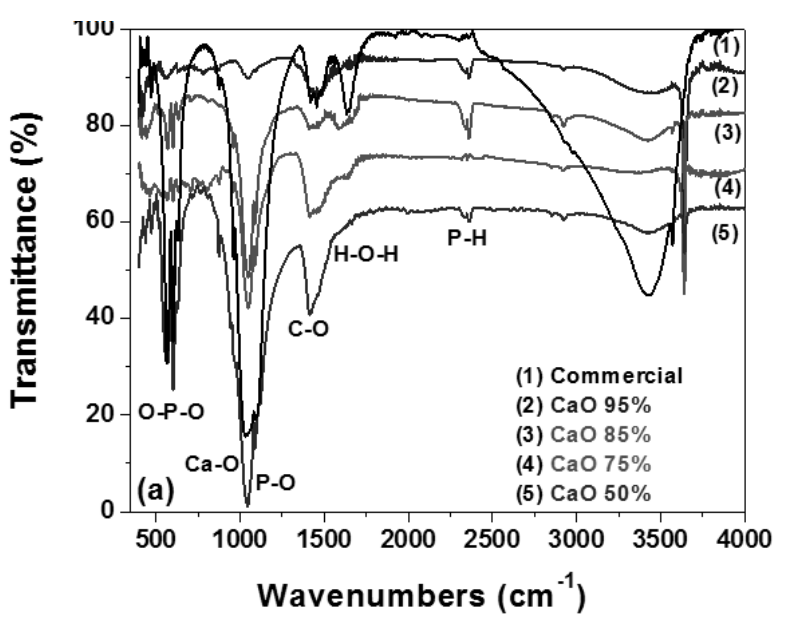

(a)

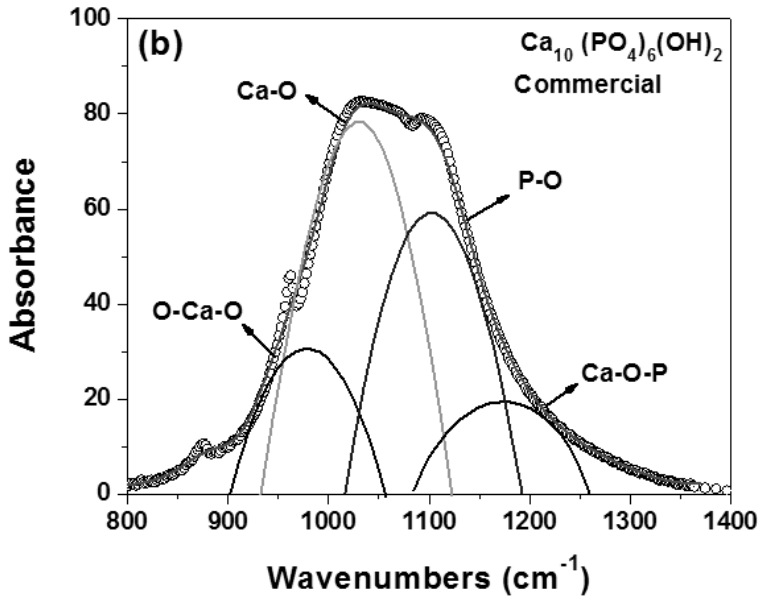

(b)

Figure 2. Spectra of FTIR (the graphs have been displaced in the transmittance scale to improve their comprehension): (a) Hydroxyapatite obtained with different percentages of $\mathrm{CaO}$, with particle size of $54 \mu \mathrm{m}$, heating ramp of $10^{\circ} \mathrm{C} / \mathrm{min}$, at a sintering temperature of $1060^{\circ} \mathrm{C}$ and 7 hours (M1-M4), and commercial nano-hydroxyapatite. (b) Deconvolution of the absorbance spectrum FTIR with high resolution in the region between $800 \mathrm{~cm}-1$ and $1400 \mathrm{~cm}-1$. 
Figure 3 shows the spectra of samples M5 to M8 corresponding to the hydroxyapatite obtained with different percentages of $\mathrm{CaO}$, with particle size of $74 \mu \mathrm{m}$, heating ramp of $15^{\circ} \mathrm{C} /$ min, under a sintering temperature of $1060^{\circ} \mathrm{C}$ and 7 hours. Additionally, it is presented a spectrum of commercial nano-hydroxyapatite in which the band around $1080 \mathrm{~cm}^{-1}$ associated to the transition corresponding to the O-P-O bonds HA flexion type (v4) (Siriphannon et al., 2002) are mainly identified. Analyzing Figure 3 , it is very clear the presence of an active mode of vibration around $571 \mathrm{~cm}^{-1}$ and 601 $\mathrm{cm}^{-1}$ corresponding to the O-P-O bonds of HA flexion type (v4) (Siriphannon et al., 2002). The vibration centered in the band of $3670 \mathrm{~cm}^{-1}$ corresponds to the $\mathrm{OH}$ - bonds of stretching type (Pramanik et al., 2005).

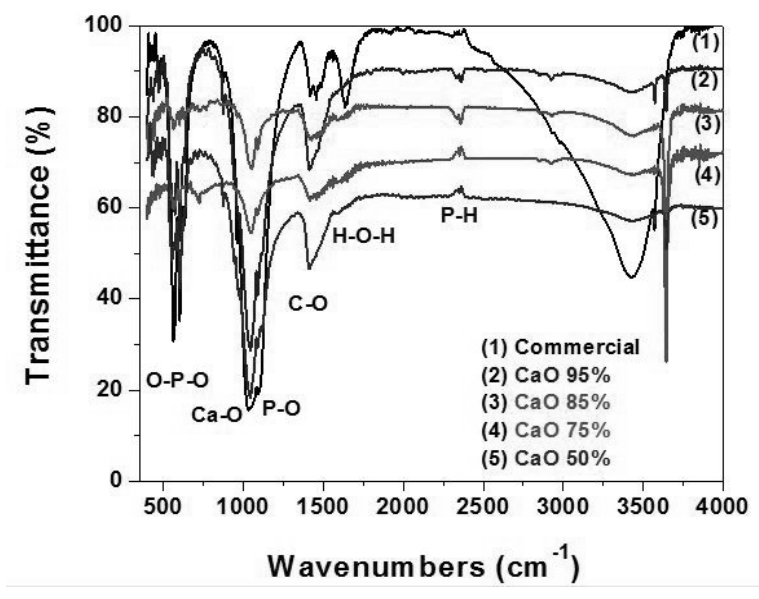

Figure 3. Spectra of FTIR (the graphs have been displaced in the transmittance scale to improve their comprehension): Hydroxyapatite obtained with different percentages of $\mathrm{CaO}$, with particle size of $74 \mu \mathrm{m}$, heating ramp of $15^{\circ} \mathrm{C} / \mathrm{min}$, under a sintering temperature of $1060^{\circ} \mathrm{C}$ and 7 hours (M5-M8), and commercial nano-hydroxyapatite.

Figure 4 shows the spectra of samples M9 and M10 corresponding to the hydroxyapatite obtained with different heating ramps of $10^{\circ} \mathrm{C} /$ $\min$ and $15^{\circ} \mathrm{C} / \mathrm{min}$, a fixed percentage of $\mathrm{CaO}$ $100 \%$, with particle size of $54 \mu \mathrm{m}$ and $74 \mu \mathrm{m}$, under a sintering temperature of $900^{\circ} \mathrm{C}$ and 5 hours; additionally, it is presented a spectrum of commercial nano-hydroxyapatite in which the band around $1080 \mathrm{~cm}^{-1}$ associated to the transition corresponding to the O-P-O bonds HA flexion type ( $v 3$ ) already described (Siriphannon et al., 2002) is presented. Figure 4 shows the vibration centered in the band of $3670 \mathrm{~cm}^{-1}$ corresponding to the $\mathrm{O}-\mathrm{H}$ bonds of stretching type (Pramanik et al., 2005). A transition band around $1415 \mathrm{~cm}^{-1}$ which corresponds to the C-O stretching type of $\mathrm{CO}_{3}{ }^{2-}$ (Pramanik et al., 2005) present in the sample is shown as well.

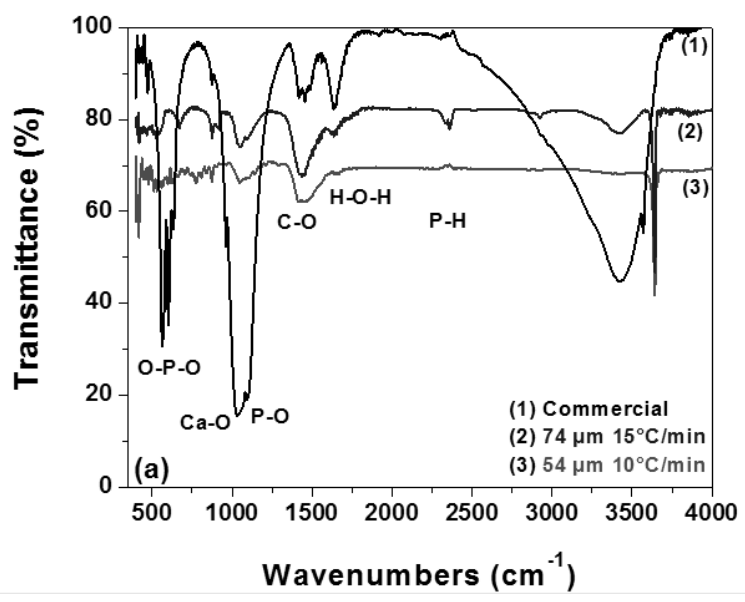

Figure 4. FTIR spectra for the hydroxyapatite obtained with different heating ramps of $\left(10^{\circ} \mathrm{C} / \mathrm{min}\right)$, a fixed percentage of $\mathrm{CaO} 100 \%$, with particle size of $54 \mu \mathrm{m}$ and $74 \mu \mathrm{m}$, under a sintering temperature of $900^{\circ} \mathrm{C}$ and 5 hours (M9, M10) (the graphs have been displaced in the transmittance scale to improve its understanding), and spectrum of the sample of commercial nano-hydroxyapatite.

On the other hand, in Figure 4 it is evident a significant reduction in the signal associated to the bands around $1080 \mathrm{~cm}^{-1}$ compared to the previous spectra. The figure shows an active mode of vibration around $571 \mathrm{~cm}^{-1}$ and $601 \mathrm{~cm}^{-1}$ for the O-P-O flexion type bonds of HA ( $v 4)$, as well as a transition band around $1415 \mathrm{~cm}^{-1}$ related to the symmetrical stretching type $\mathrm{C}-\mathrm{O}$ of $\mathrm{CO}_{3}{ }^{2-}$ (Siriphannon et al., 2002). The vibration centered in the band of $3670 \mathrm{~cm}^{-1}$ corresponds to the bonds O-H- of stretching type (Delgado et al., 1996). 


\section{2 $\mathrm{X}$ ray diffraction}

A characterization through $\mathrm{X}$ ray diffraction for the commercial $\mathrm{HA}\left(\mathrm{Ca}_{10}\left(\mathrm{PO}_{4}\right)_{6}(\mathrm{OH})_{2}\right)$ was conducted to determine its structural nature. It is compared to the X-ray diffractograms obtained for the samples synthesized from solid residues of eggshells. International patterns of indexation taken from the JCPDF 01-074-0565 database obtained from the "Inorganic crystal structure database" (ICSD) were considered for the X-ray diffraction analysis. Figure 5 shows the X-ray diffractograms obtained for the samples that are between M1 and M4 with different percentages of $\mathrm{CaO}$, with particle size of $54 \mu \mathrm{m}$, heating ramp of $10^{\circ} \mathrm{C} / \mathrm{min}$, under a sintering temperature of $1060^{\circ} \mathrm{C}$ and 7 hours of treatment.

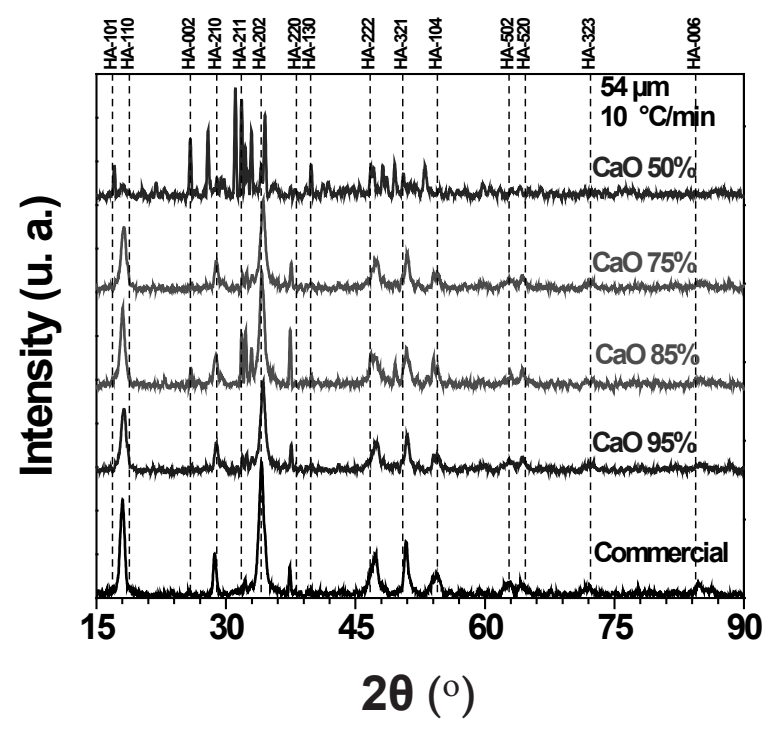

Figure 5. X-ray diffraction pattern for the hydroxyapatite obtained with different percentages of $\mathrm{CaO}$, with particle size of $54 \mu \mathrm{m}$, heating ramp of $10^{\circ} \mathrm{C} / \mathrm{min}$, under a sintering temperature of $1060^{\circ} \mathrm{C}$ and 7 hours (M1 M4). The diffraction pattern of the commercial nanohydroxyapatite sample is included.

Figure 6 shows the X-ray diffractograms obtained for the samples that are between M5 and M8 with different percentages of $\mathrm{CaO}$, with particle size of $74 \mu \mathrm{m}$, heating ramp of $15^{\circ} \mathrm{C} / \mathrm{min}$, under a sintering temperature of $1060^{\circ} \mathrm{C}$ and 7 hours of treatment. It can be analyzed from Figures 5 and 6 that the main peaks characteristic of the hexagonal Hydroxyapatite with spatial group P63/m-176 appeared. The characteristic phases with the high intensity crystallographic planes (110), (210), (202), (220), (222), (321) y (104), among others, are observed. It is also seen that while the percentage of $\mathrm{CaO}$ decreases for both sample groups, different crystallographic planes appeared, which could imply defunctionalization of the conjugated complexes conforming the hydroxyapatite. For the particular case of $\mathrm{CaO}$ $50 \%$ the diffractograms of both samples (M4 and M8) show variations in position and intensity from the diffraction maximum values, suggesting the emergence of secondary phases.

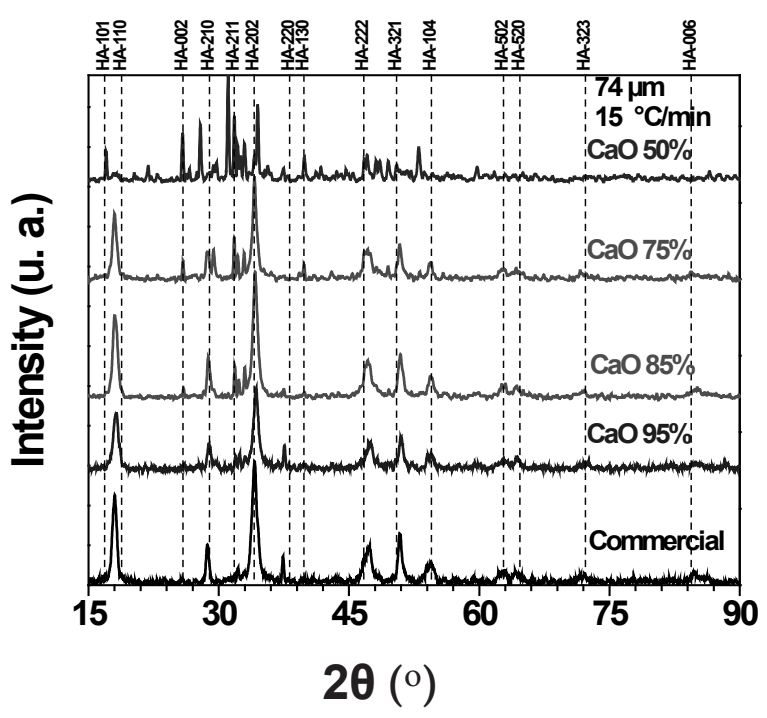

Figure 6. X-ray diffraction pattern for the Hydroxyapatite obtained with different percentages of $\mathrm{CaO}$, with particle size of $74 \mu \mathrm{m}$, heating ramp of $15^{\circ} \mathrm{C} / \mathrm{min}$, under a sintering temperature of $1060^{\circ} \mathrm{C}$ and 7 hours M5 - M8). The diffraction pattern of the commercial nano-hydroxyapatite sample is included.

\subsection{Scanning electron microscopy}

Figure 7 shows two micrographs obtained by scanning electron microscopy (SEM) for a sample of hydroxyapatite $\left(\mathrm{Ca}_{10}\left(\mathrm{PO}_{4}\right)_{6}(\mathrm{OH})_{2}\right)$ synthesized from solid residues of eggshells. Sample M1 presents morphology of irregular grains forming agglomerates. The images show that the particles present an irregular shape, with size close to 10 $\mu \mathrm{m}$, forming agglomerate until forming groups of $50 \mu \mathrm{m}$. These agglomerates are due to the porogenic agent in the manufacturing 
process of the samples, which is strongly related to the molecular formation registered in the vibrational modes of the HA, analyzed in the FTIR results (Figs. $2-4$ ) and the corresponding present phases observed by the results of the X-ray diffraction (Figs. 5 and 6). Additionally, the particle surface in the synthesized HA has high roughness. This result is significant since the particle shape and its geometry can be determinant in the final response at the moment of the biomaterial implanting.
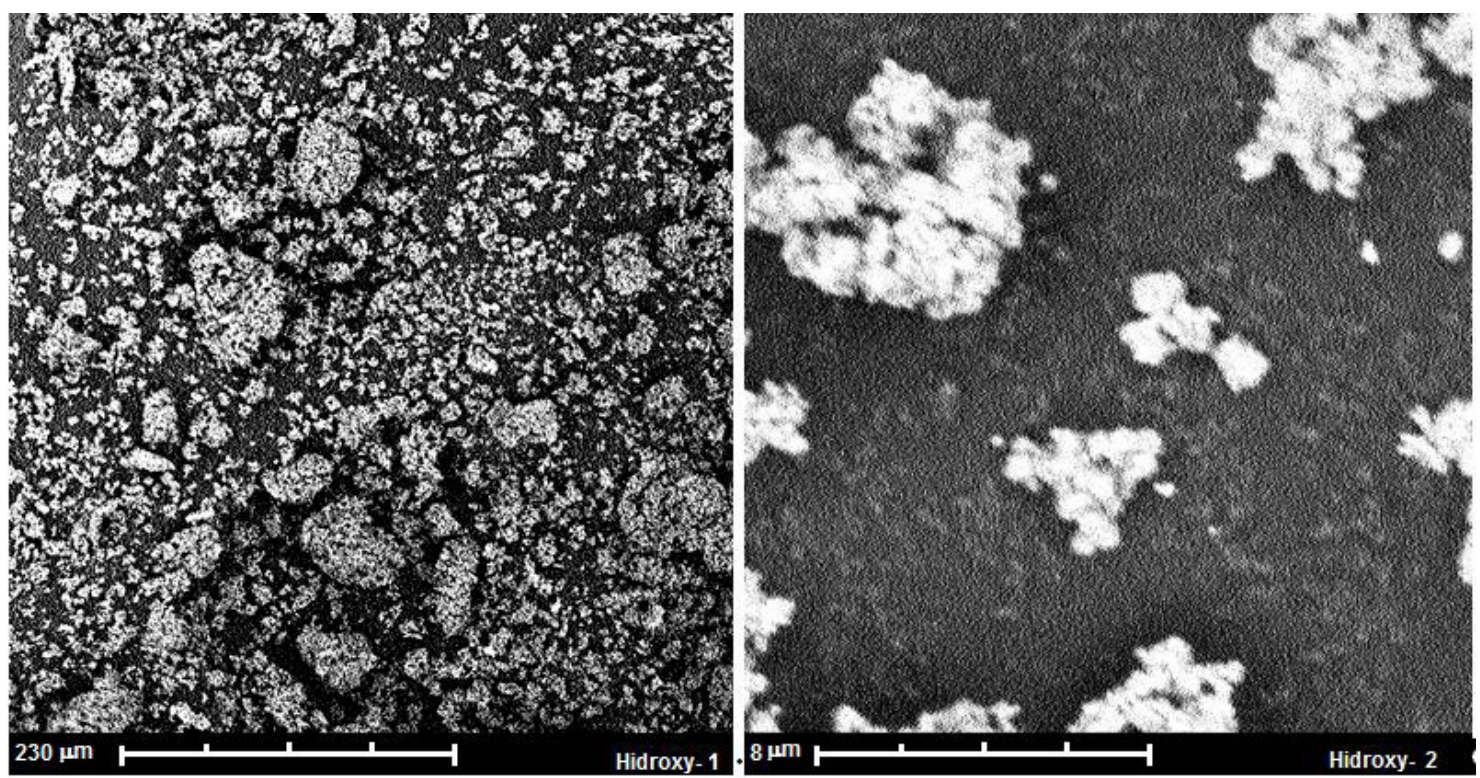

\section{Acknowledgements}

This work has been developed thanks to the support of the seedbed of Research in Advanced Materials for Micro and Nanotechnology (IMAMNT) of the Universidad Autonoma de Occidente, to the technological support of the Interdisciplinary Institute of Sciences (IIC) of the Universidad del Quindio, and to the Center of Excellence in New Materials (CENM) of the Universidad del Valle.

Figure 7. SEM micrography for ceramic powder of HA obtained from eggshell.

\section{Conclusions}

The results of the X-ray diffraction confirm the synthesis of hydroxyapatite (HA) obtained from eggshell, due to the presence of constituent phases of the (HA). For the M4 and M8 samples a percentage equal to $50 \%$ of the $\mathrm{CaO}$ and $\mathrm{Ca} 3(\mathrm{PO} 4) 2$ components is taken into account. The results presented show the diffractions corresponding to the crystallographic planes of the cubic and hexagonal structures, forming a mixture of phases of the $\mathrm{Ca}, \mathrm{PO} 4 \mathrm{y}(\mathrm{OH})_{2}$ components, with small quantities of beta-tricalcium phosphate. Active modes of vibration corresponding to the $\mathrm{CO} 3$ bonds and vibrational bands associated to PO4 were also determined. 
FENAVI (2014). Producción público. [ONLINE] Available at: http://www.fenavi.org/index. php?option $=$ com_content $\&$ view $=$ article $\&$ id $=247$ 2\&Itemid=1330\#. [Last Accessed 19 Abril 2015].

Franco, G.R., Laraia, I.O., Maciel, A.A., Miguel, N.M., Dos Santos, G.R., Fabrega-Carvalho, C.A., Pinto, C.A., Pettian, M.S. \& Cunha, M.R. (2013) Effects of chronic passive smoking on the regeneration of rat femoral defects filled with hydroxyapatite and stimulated by laser therapy. Injure 44 (7), 908 - 913.

Ginebra, M.P., Traykova, T., \& Planell, J.A. (2006). Calcium phosphate cements as bone drug delivery systems: a review. Journal of Controlled Release 113 (2), 102-110.

Lee, S.J., \& Oh, S.H. (2003). Fabrication of calcium phosphate bioceramics by using eggshell and phosphoric acid. Materials Letters 57 (29). 4570-4574.
Sadat-Shojai, M., Khorasani, M., DinpanahKhoshdargi, E. \& Jamshidi, A. (2013). Synthesis methods for nanosized hydroxyapatite with diverse structures. Acta Biomaterialia 9 (8), 7591-7621.

Rivera, E.M., Araiza, M., Brostow, W., Castaño, V.M., Díaz-Estrada, J.R., Hernández, R. \& Rodríguez, J.R. (1999) Synthesis of hydroxyapatite from eggshells. Materials Letters 41 (3), 128-134.

Siriphannon, P., Kameshima, Y., Yasumori, A., Okada, K., \& Hayashi, S. (2002). Formation of hydroxyapatite on $\mathrm{CaSiO} 3$ powders in simulated body fluid. Journal of the European Ceramic Society 229 (4), 511-520.

Pramanik, S., Agarwaly, A.K. \& Rai K.N. (2005). Development of High Strength Hydroxyapatite for Hard Tissue Replacement. Trends Biomater. Artif Organs 19 (1), 46-51.

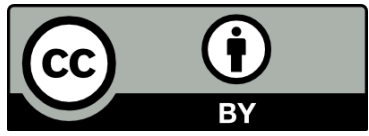

Revista Ingeniería y Competitividad por Universidad del Valle se encuentra bajo una licencia Creative Commons Reconocimiento - Debe reconocer adecuadamente la autoría, proporcionar un enlace a la licencia e indicar si se han realizado cambios. Puede hacerlo de cualquier manera razonable, pero no de una manera que sugiera que tiene el apoyo del licenciador o lo recibe por el uso que hace. 